\title{
Protected water habitats in the landscape area "Augšdaugava"
}

\author{
Elmīra Boikova*1, Lelde Eṇğele ${ }^{2}$, Vita Līcīte', Uvis Suško ${ }^{1}$ \\ 1 Institute of Biology, University of Latvia, Jelgavas Street 1, Riga, Latvia, LV-1004 \\ 2 The Latvian Fund for Nature, Blauman, Street 32-8, Riga, Latvia, LV-1011 \\ * Corresponding author: Elmira.Boikova@lu.lv
}

\begin{abstract}
The "Augšdaugava" protected landscape area was established already in 1990, but the elaboration of the environment protection plan for this largest landscape area in Latvia is still in progress. The nature park "Daugavas loki" as part of this landscape area was established in 1990 and the nature park already has the protection and management plan (2010-2022). The upper Daugava river valley forms the central axis of the protected landscape area and is included in the Natura 2000 network. The complex of the Daugava River with nine large meanders and small, natural unaltered rivers, crossing the ravines, belongs to the Annex I habitat type 3260. This area is also rich in mineral springs and spring fens. There are about 30 lakes with different eutrophication impacts in the area. The possible threats, nature values, and water ecosystem services are discussed.
\end{abstract}

Keywords: The Daugava River, lakes and watercourses, NATURA 2000, ecosystem services

\section{The habitats of the Daugava River and its tributaries}

The flow of the Daugava River forms the main axis of the landscape protection area "Augšdaugava". Between the Latvian state border near Piedruja and Daugavpils city in $98 \mathrm{~km}$ length, the River Daugava and its valleys with unique nine meanders is an important river habitat complex. It consists of river sections with different flow rates, soils, plant and animal communities. The most typical river biotopes according to the European Union protected habitats classification in Latvia are:

- the river stretches with stony, shingly or gravelly river bed, with average flow velocity higher than $0.2 \mathrm{~m} / \mathrm{s}$ as well as natural unaltered river stretches regardless of flow velocity, identified as Annex I habitat type 3260,

- the muddy riverbanks with nitrogen loving pioneer vegetation - 3270,

- the riverbank with a stripe of vegetation (wet tall herb edge communities) 6430 . 
The Daugava's River dominant habitat is habitat type 3260 and therefore this unmodified ecosystem represents one of the most important and unique habitat types in Latvia and the European Union. Muddy riverbanks with nitrogen-loving annual pioneer vegetation form a specific habitat, the distribution of which is associated only with large rivers. The habitat is found only at low water levels, exposing the riverbed, where the vegetation characteristic of the habitat is forming. In the case of the Daugava River, this habitat was mapped in September 2011 along the banks and islands in 19 places with a total area of 20 ha. During the survey, the width of the exposed bed in the habitat was more than five meters and the characteristic species of this habitat were Chenopodium rubrum, Bidens cernus, B. tripartita, and Limosella aquatica.

River habitats are very important for many plant and animal species, they serve as a natural route for the migration of species, as well as ensure the existence of floodplain grasslands and forests dependent on the flood regime. Particularly valuable are river streams with rocky or pebbly soils, which are the only habitat for species that have adapted to life in fast-flowing, oxygen-rich waters. Oxygen-rich water in streams significantly accelerates the decomposition of organic matter and, consequently, the self-purification of water. In Latvia, it is a relatively rare habitat - only 17620 ha, which is $0.3 \%$ of the country (EU protected habitats in Latvia, interpretation manual, $2^{\text {nd }}$ revised edition, 2013).

The Daugava River water quality and hydrobiology were already well documented by scientists from the Institute of Biology (Кумсаре, 1967; Kumsare, 1972; Рудзрога, Друвиетис, 1984; www.kn.lv/raksti_data/422DAUGAVA, 2007) and the University of Daugavpils (Gruberts, 2006; Gruberts and Druvietis, 2006). By the Latvian Center for Environment, Geology, and Meteorology a monitoring assessment of the River Daugava has been carried out. In the last 20 years, an average of $64 \%$ of $N$ tot runoff and $92 \%$ of P tot runoff in the Daugava River loads are caused by the transboundary runoff (Belarus and Russia). In Latvia, the point sources are mainly responsible for loads to the Daugava River. Not only the increase of nutrient load - nitrogen and phosphorus at the border, but also the presence of toxic priority substances creates risks and threats to the quality of the Daugava River in the territory of Latvia. The environmental risk from waste disposal facilities in the Belarusian part of the Zapadnaja Dvina (Daugava) river basin is one of the threats as well (www.lvgmc. gov.lv). Recently, the quality indicators of the Daugava River are relatively good, however, they do not meet the quality requirements of the priority fish waters' quality.

Mapping of habitats of EU importance in the Daugava River itself and its tributaries was performed in 2017-2018 in the framework of the project Nature Census: https://www.skaitamdabu.gov.lv/public/eng. These results illustrate that Daugava river quality is on a medium/good level and this is in good agreement with National environment assessment data (2016-2019), based on EU Water framework directive EQ standards evaluation. 


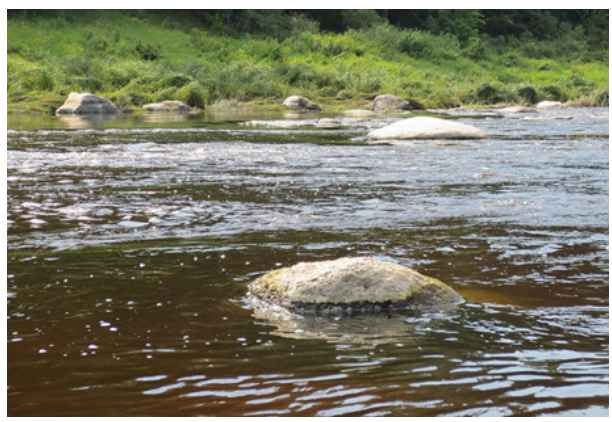

Figure 1. Daugava River by Indrica River, habitat 3260

(Photo: J. Smalinskis).

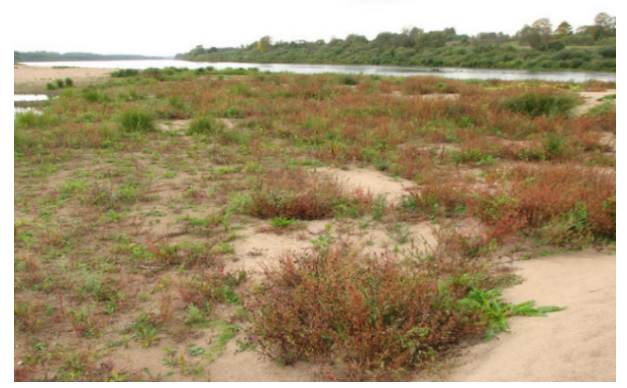

Figure 2. Daugava River near

the Dorbachova iland, habitat 3270 (Photo: A. Opmanis).

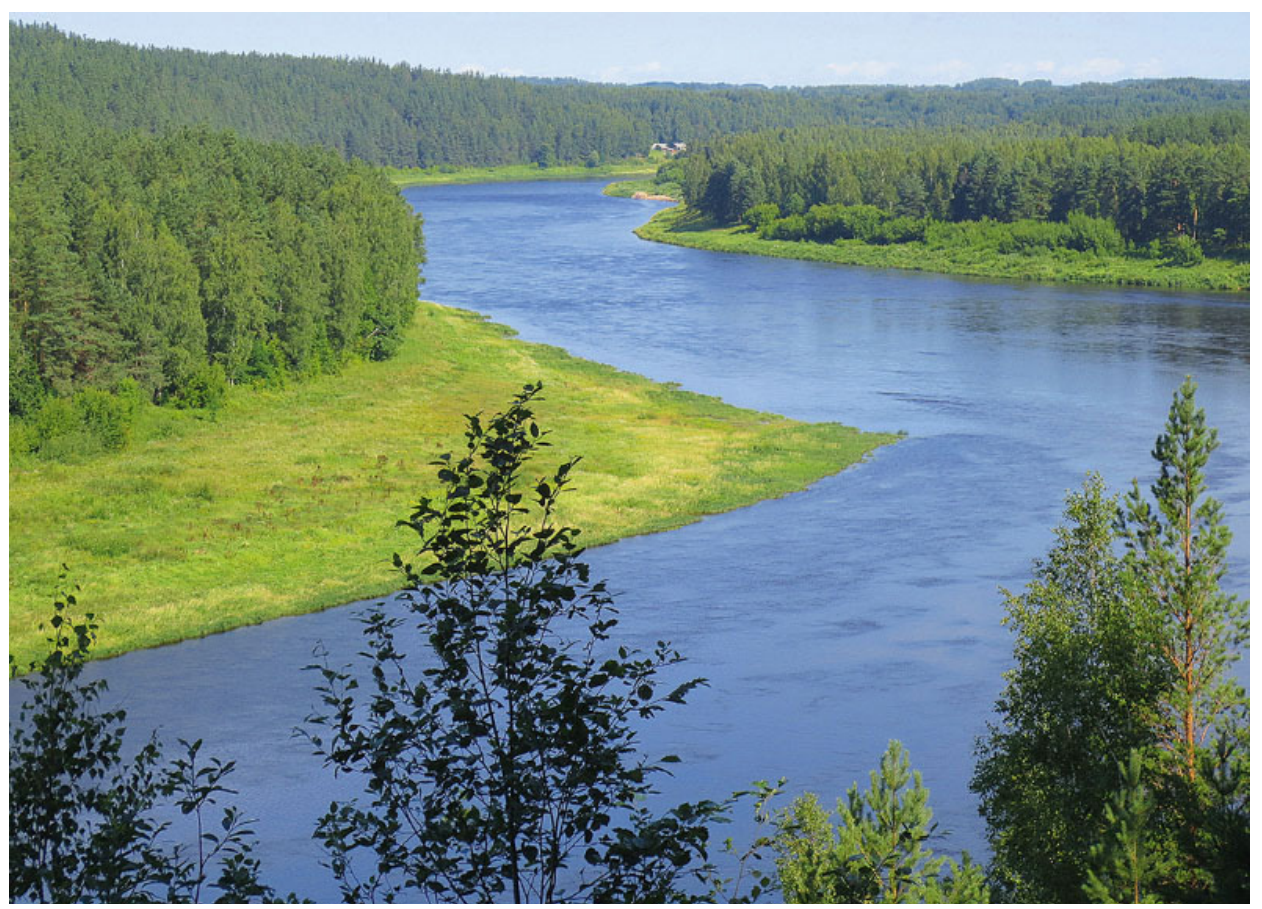

Figure 3. Daugava River meanders and valley from the Ververu Cliff (Photo: J. Smalinskis).

In the investigated area the Daugava River is rich in small tributaries which correspond to the Annex I habitat 3260. All these small rivers penetrate the Quaternary glacial sediments and wash out the fine-grained rubble. Their beds have a collection of boulders, pebbles, forming the steep rapids. There are also beautiful springs classified as the Annex I habitat 7160. 


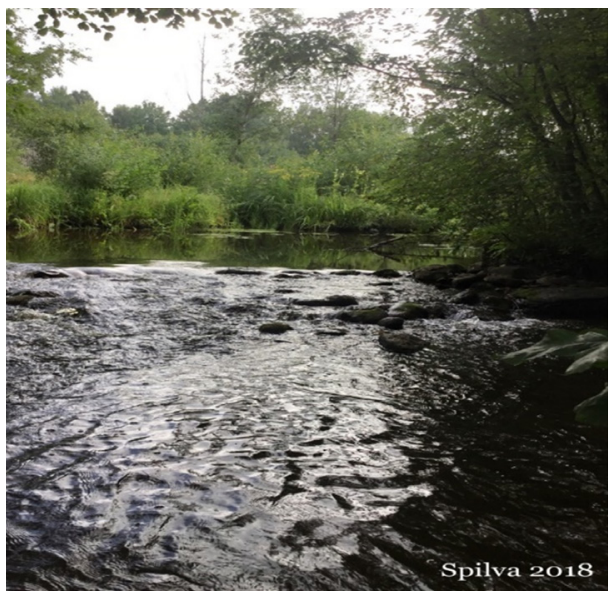

Figure 4. River Rudṇa, habitat 3260.

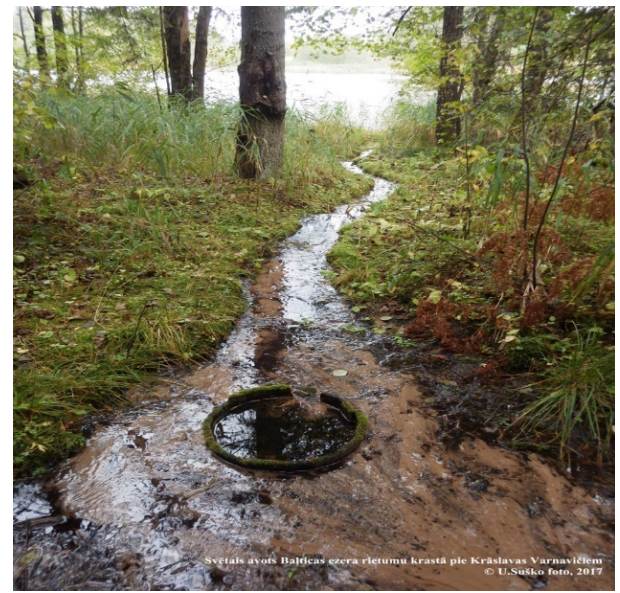

Figure 5. Spring near the lake, habitat 7160.

Small and rapid rivers are habitats for rheophilic species, including rare and threatened ones. The total overgrowth does not exceed $30 \%$ of optimal conditions, because a higher proportion decreases the flow velocity and favours the accumulation of nutrients. In several small rivers, beaver activity was detected as a threat to the rapid flow of a stream. In some places, shading is too intensive and sedimentation process from branches and leaves was observed.

\section{Protected landscape area lakes and their habitats}

If in the case of rivers their main function is the transportation of matter and energy flow, then for lakes this function is matter and energy accumulation. There are 31 lakes in the investigated area and all of them belong to the Daugava River catchment area. More detailed research of these lakes' quality and vegetation started only in 1990-ies (Suško, 1991, 1993, 1994, 1995, 1996; Suško and Bambe, 2002; Suško and Evarts-Bunders, 2010; Suško et al., 2018).

There is only one lake Varnaviči which corresponds to habitat 3130 of EU importance - Lakes with oligotrophic to mesotrophic plant communities. Lake Varnaviči is a very deep $(9 \mathrm{~m})$ mesotrophic lake of good quality, therefore maintaining, protecting, and improving its quality is a very important nature protection priority. This lake type is very rarely found in Latvia, it occupies in total 5570 ha or only $0.08 \%$ of the territory of the country.

All other 30 lakes belong to the habitat type 3150 - natural eutrophic lakes with Magnopotamium or Hydrocharition-type vegetation. These are lakes with the diverse and rich vegetation of submerged and floating plant species, with 
the water $\mathrm{pH}$ mostly exceeding value 7 . The habitat comprises clear water and brown water lakes with appropriate vegetation. The area occupied by this lake type is 66330 ha $-1 \%$ of the country. In Latvia the following habitat variants are distinguished:

- 3150_1: clear water lakes with submerged vegetation,

- 3150_2: brown-water lakes with diverse vegetation,

- 3150_3: oxbow lakes.

Fifteen lakes are classified as the first variant (3150_1), seven of them are of good quality, eight - of lowered water quality but 14 lakes - to the variant 3150_2 and only two of them are of good quality, others medium only.

In terms of nature values, the most important lakes are good quality eutrophic clearwater lakes, dyseutrophic brown-water lakes (mostly anthropogenically not affected, pollution-sensitive), and watershed lakes with small catchment areas and long water exchange period, and lakes located in forests.

Most of the studied lakes have a very significant landscape and aesthetic value. This is especially true for Lake Šilovka, which is surrounded by dry pine forests and is considered to be the largest and most beautiful lake in the protected landscape area.

Lakes have been affected by several factors related to human activities - landuse change, hydromelioration works and the resulting changes in the lake water level, arbitrary expansion of catchment areas as a result of excavation of natural watersheds, the inflow of nutrients from the agricultural lands in their catchment areas (arable land, pasture fertilization, farms, dairies, livestock swimming in lakes, mineral fertilizers, etc.), inhabited areas (incompletely treated or not drained), forests (clear-cutting, forest fertilization), as well as nutrient pollution of lakes caused by intensive recreation (bathing areas, saunas on the shores of lakes and guest houses). However, the lakes are also affected by their natural eutrophication processes.

In lakes, phosphorus $(\mathrm{P})$ is commonly the main nutrient limiting primary production. Therefore, controlling the human-induced external load of $\mathrm{P}$ to lakes is one of the main challenges in lake management. In Finland data were collected from 27 lakes and their trophic state varied from mesotrophic to hypereutrophic These lakes were chosen randomly among those where suitable data (P load measurements based on discharge and $\mathrm{P}$ concentration measurements and thus independent on land use information) were available. The results showed that catchment area to lake area ratio $(A \mathrm{C} / A \mathrm{~L})$, cultivated catchment area to lake area ratio $(A \mathrm{~F} / A \mathrm{~L})$, and percentage of cultivated land in the catchment $(F \%)$ can be used to predict the risk of exceeding the critical P load. However, $A F / A L$ had the best predicting power. This was because it contained information on both land use and catchment area variations (Horppila et al., 2019). Already according to previous investigations in watersheds with low transport. 


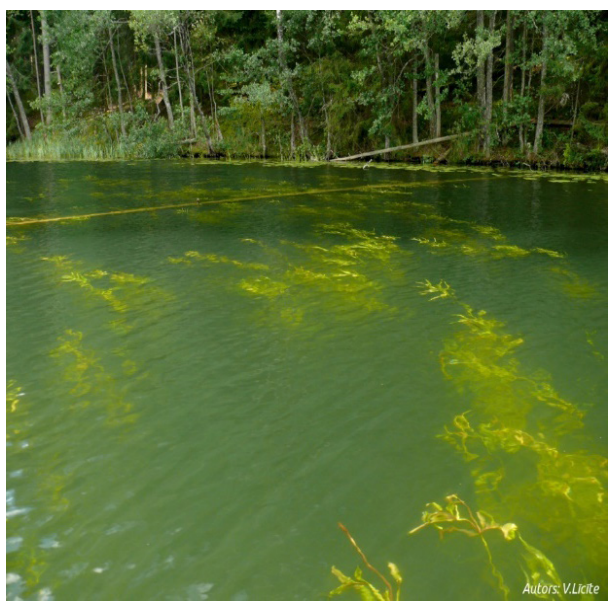

Figure 6. Lake Varnaviču, habitat 3130.

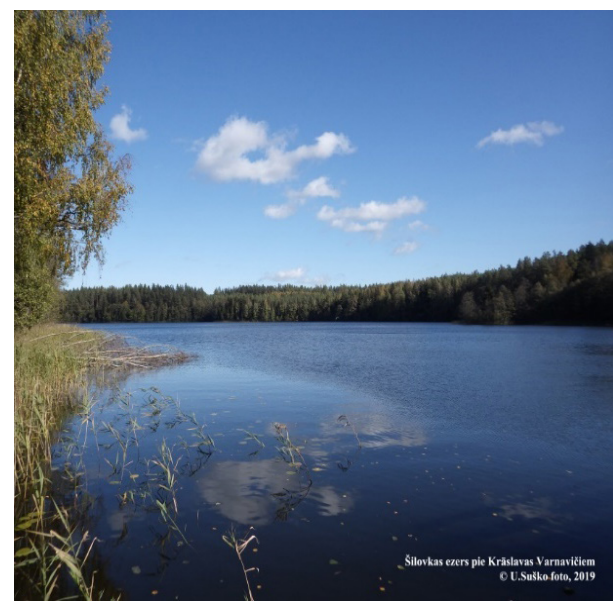

Figure 7. Lake Šilovka, habitat 3150.

Capacity, in-lake processes and near-shore land use/cover tended to be more influential, whereas, in watersheds with high transport capacity, land use/cover across the entire watershed was important for explaining lake chemistry. Thus, although land use is a key driver of nutrient loading to lakes, the extent to which it influences water quality can vary with watershed transport capacity (Fraterrigo and Downing, 2014). Forests clearcutting is one of the factors changing the nutrient flow to the lakes. Therefore during the development of the protection plan for the landscape area "Augšdaugava" for the first time according to expert V. Licite (2021) recommendation, we are proposing to restrict the clearcutting of forests in three lakes (Baltica, Šilovka, and Varnaviču) catchment areas to diminish the nutrient flow to the lakes.This could be a good management practice for the future to prevent the eutrophication processes of water ecosystems.

\section{Acknowledgements}

The Landscape area "Augšdaugava" protection and management plan for period 2022-2034 is financed by the project 'Preconditions for better biodiversity preservation and ecosystem protection in Latvia', or simply the 'Nature Census', and co-funded by the European Union Cohesion Fund: www.daba.gov.lv 


\section{References}

European Union Protected Habitats In Latvia. 2013. Interpretation manual $2^{\text {nd }}$ edition. Ed. A. Auniņš, p. 359.

Daugavas ekologiiskā stāvokḷa novērtējums. 2007. LU Bioloǵijas institūts, Salaspils. www.kn.lv/ raksti_data/422DAUGAVA, ATSKAITE.doc, 58. lpp.

Fraterrigo, J. M., Downing, J. A. 2014. The influence of land use on lake nutrients varies with watershed transport capacity. Ecosystems, $15 \mathrm{p}$.

Kumsare, A. 1972. Zur hydrobiologischen Rayonierung der Daugava. Verh. Internat. Verein. Limnol. 18: 751-755.

Gruberts, D. 2006. Palu pulsa koncepcija Daugavas vidusteces palien̦u ezeru ekologijā. Promocijas darbs. Daugavpils, 1.-152. lpp.

Gruberts, D., Druvietis, I. 2006. Impact of floods on composition, biomass, and diversity of phytoplankton communities of the Middle Daugava, in Latvia. In: Proceedings of $6^{\text {th }}$ International Symposium on Use of Algae for Monitoring Rivers. Ács, E., Kiss, K. T., Padisak, J., Szabo, K. E. (eds.). Hungary, Baltonfüred, 12-16 Sept. Pp. 54-59.

Horppila, J., Holmroos, H., Niemistö, J., and Tammeorg, O. 2019. Lake catchment characteristics and external P load-cultivated area/lake area ratio as a tool for evaluating the risk of eutrophication from land use information. Boreal Environment Research. 24: 13-23.

Kumsare, A. 1972. Zur hydrobiologischen Rayonierung der Daugava. Verh. Internat. Verein. Limnol. 18: 751-755.

Lìcīte, V. 2020. Sertificēta eksperta (sugu un biotopu aizsardzības jomā) atzinums par izpēti, stāvokḷa analīzi, aizsardzības un apsaimniekošanas pasākumu noteikšanu aizsargājamā ainavu apvidus “Augšdaugava” ezeros: Balticas ezers, Butišku ezers, Šilovkas ezers, Varnaviču ezers. 27.02.2020.

Nacionālais ziṇojums par vides stāvokli 2016-2019. www.meteo.lv

Suško, U. 1991. Mazā najāda Najas minor All. - jauna suga Latvijas florā. Retie augi. Rìga, 6.-9. lpp.

Suško, U. 1993. Varnaviču ezeraines morfometrija. DPU Dabas aizsardzības Inf. Biḷ. Daugavpils, 5, 14.-16. lpp.

Suško, U. 1994. Jaunas ziņas par Ilūkstes lielezeraines un citu Latvijas apgabalu reto un aizsargājamo augu atradnēm. Daba un Muzejs. Rīga, 5, 36.-42. lpp.

Suško, U. 1995. Ilūkstes lielezeraines glīvenes Potamogeton L. Maǵistra darbs biolog̣ijā. Daugavpils, 200 lpp.

Suško, U. 1997. Augšdaugavas dabisko ezeru botāniski-limnologisko pētījumu rezultāti Indricas un Varnaviču ezerainēs. Daba un Muzejs. Rīga, 7, 33.-39. lpp.

Suško, U., Bambe, B. 2002. Floristiskie pētījumi Augšzemes un Latgales ezeros. Retie augi. Rīga, 79.-94. lpp.

Suško, U., Evarts-Bunders, P. 2010. Botānisko pētījumu vēsture Dienvidaustrumlatvijā. Latvijas Veǵetācija. 21: 101-125.

Suško, U., Skrinda, I., Grīnberga, L., and Zviedre, E. 2018. Nozīmīgākie 2015.-2017. gada reto ùdensaugu atradumi Latvijas ezeros. Latvijas Universitätes 76. zinātniskā konference, Biologijas fakultātes Hidrobioloǵijas katedra, sekcijas "Latvijas ūdeñu vides pētījumi un aizsardzība" tēzes. 2018. gada 30. janvāris, 3. lpp.

Кумсаре, А. Я. 1967. Гидробиология реки Даугавы. Рига: Зинатне, с. 3-186.

Рудзрога, А. И., Друвиетис, И. Ю. 1984. Альгологические исследования реки Даугава. Санитарное состояние реки Даугавы. Даугавпилс, с. 24-29. 